\title{
PRESSURE GROUPS, POLITICS AND DEMOCRACY IN BRITAIN
}

\author{
Second Edition
}

\author{
WYN GRANT \\ Professor of Politics, University of Warwick
}

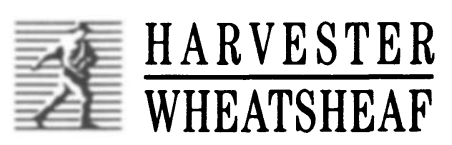

New York London Toronto Sydney Tokyo Singapore 


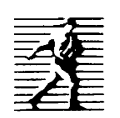

First published 1995 by

Harvester Wheatsheaf

Campus 400, Maylands Avenue

Hemel Hempstead

Hertfordshire, HP2 7EZ

A division of

Simon \& Schuster International Group

ISBN 978-0-333-76324-7 ISBN 978-1-349-15022-9 (eBook)

DOI 10.1007/978-1-349-15022-9

(C) Wyn Grant, 1995

Reprint of the original edition 1995

All rights reserved. No part of this publication may be reproduced, stored in a retrieval system, or transmitted, in any form, or by any means, electronic, mechanical, photocopying, recording or otherwise, without prior permission, in writing, from the publisher.

Typeset in 10/12pt Times

by Dorwyn Ltd, Rowlands Castle, Hants.

Library of Congress Cataloging in Publication Data

Grant, Wyn.

Pressure groups, politics and democracy in Britain/Wyn Grant. 2nd ed.

p. cm. - (Contemporary political studies series)

Includes bibliographical references and index.

ISBN 978-0-7450-1672-6

1. Pressure groups - Great Britain. 2. Lobbying-Great Britain.

3. Great Britain. Parliament. House of Commons. I. Title.

II. Series.

JN329.P7G73 1995

322.4'3'0941-dc20

94-30434

CIP

British Library Cataloguing in Publication Data

A catalogue record for this book is available from the British Library

ISBN 978-0-7450-1672-6 (pbk) 


\section{CONTEMPORARY POLITICAL STUDIES SERIES}

Series Editor: John Benyon, Director, Centre for the Study of Public Order, University of Leicester

A series which provides authoritative yet concise introductory accounts of key topics in contemporary political studies.

Other titles in the series include:

UK Political Parties since 1945

Edited by ANTHONY SELDON, Institute of Contemporary British History

Politics and Policy Making in Northern Ireland MICHAEL CONNOLLY, University of Ulster

Local Government and Politics in Britain

JOHN KINGDOM, Sheffield Polytechnic

British Political Ideologies

ROBERT LEACH, Leeds Polytechnic

British Government: The Central Executive Territory Peter madgwick, Professor Emeritus, Oxford Polytechnic

Race and Politics in Britain

SHAMIT SAGGAR, Queen Mary and Westfield College, University of London

Selecting the Party Leader MALCOLM PUNNETT, University of Strathclyde

Does Parliament Matter?

PHILIP NORTON, University of Hull

The President of the United States

DAVID MERVIN, University of Warwick

The Politics of Economic Policy WYN GRANT, University of Warwick

Introduction to International Politics

DEREK HEATER, formerly of Brighton University and

G.R. BERRIDGE, University of Leicester

Elections and Voting Behaviour in Britain (2nd Edition)

DAVID DENVER, Lancaster University

The Law and Politics of the British Constitution

PETER MADGWICK and DIANA WOODHOUSE, Oxford Brookes University 


\section{PRESSURE GROUPS, POLITICS AND DEMOCRACY IN BRITAIN}




\section{CONTENTS}

Preface

I INTRODUCTION: THE KEY CHARACTERISTICS OF PRESSURE GROUPS

What is a pressure group?

Social movements

Political parties

A working definition of a pressure group

Typologies of groups

A classification of group strategies

Pressure groups and democracy

2 PRESSURE GROUPS AND THE POLITICAL SYSTEM 27

$\begin{array}{ll}\text { Pluralism } & 28\end{array}$

Policy networks and policy communities $\quad 34$

Corporatism: yesterday's theory? $\quad 37$

The liberal critique of pressure groups $\quad 39$

3 HOW PRESSURE GROUPS INFLUENCE WHITEHALL AND THE POLITICAL AGENDA 47

Getting issues on the political agenda 49

Food additives: a case study of issue emergence 51

Influencing the executive branch of government 57

Policy implementation and enforcement 63 
4 PARLIAMENT 66

Ways of using Parliament $\quad 67$

$\begin{array}{ll}\text { Professional lobbyists } & 74\end{array}$

$\begin{array}{ll}\text { Conclusions } & 78\end{array}$

5 EXERTING PRESSURE OUTSIDE WHITEHALL AND WESTMINSTER $\quad 80$

Pressure groups and the party system $\quad 80$

Pressure groups and the media $\quad 84$

Pressure groups and the courts $\quad 89$

Local government 91

6 PRESSURE GROUPS AND THE EUROPEAN UNION 98

The decline of the national route? $\quad 100$

European-level pressure groups $\quad 104$

The targets of representation $\quad 110$

The leading role of big business $\quad 114$

$\begin{array}{ll}\text { European corporatism? } & 121\end{array}$

7 THE EFFECTIVENESS OF PRESSURE GROUPS 125

Why measuring pressure-group influence is difficult 127

A typology of factors affecting pressure-group effectiveness $\quad 130$

$\begin{array}{ll}\text { Conclusions } & 149\end{array}$

8 CONCLUSIONS: PRESSURE GROUPS AND DEMOCRACY 153 The legacy of Thatcherism $\quad 155$

Labour in office? $\quad 157$

The case for pressure groups reviewed $\quad 159$

The limits to pressure-group power $\quad 164$

$\begin{array}{ll}\text { References } & 166\end{array}$

$\begin{array}{ll}\text { Index } & 177\end{array}$ 


\section{Preface}

This book seeks to provide a general introduction to the role of pressure groups in British democracy for those relatively unfamiliar with the subject. Readers who wish to follow up the subject in more depth by reading some of the academic literature on pressure groups can refer to the list of references at the end of the book.

Since the first edition of this book was published, a considerable amount of important new work has been undertaken on pressure groups in Britain. Of particular significance has been the British Interest Groups Project at Aberdeen University coordinated by Grant Jordan and his colleagues (referred to hereafter in this book as 'the Aberdeen group'), and the work on lobbying at the European Union level undertaken by Sonia Mazey of Cambridge University and Jeremy Richardson at Warwick University.

As well as making use of what is now an extensive literature on pressure groups, this book draws on interviews I have conducted over the years with pressure-group officials, politicians and civil servants. Some of this research has been funded by the Economic and Social Research Council and by the Nuffield Foundation.

I would like to express my appreciation to the series editor, John Benyon, for originally suggesting that I should write this book. The second edition was prepared while I was a Visitor at Nuffield College, Oxford. I would like to thank the Warden and Fellows of Nuffield College for inviting me to be a Visitor, and particularly 
my sponsor, Vincent Wright. While I was there I had the opportunity of meeting Mancur Olson again. I do not agree with all his views, but I have always found his work stimulating. Not all academics who have accomplished so much are as open or approachable, or as willing to discuss their work with anyone, whatever their standing.

This book is dedicated to the memory of my uncle, Sidney Field, who sadly died before publication of the first edition. Conversations I heard as a child in his newsagent's shop in Plumstead, SE18 helped to stimulate my interest in politics, and gave me my first lessons in looking for the story behind the story in the day's newspapers.

I would like to thank Sophia Grant for her help with materials on the Motor Cycle Action Group. As always, special thanks are due to my wife, Maggie, who was writing up her own work on pressure groups at the same time as I was working on this second edition.

Wyn Grant Oxford, June 1994 